CENTRE POUR LA RECHERCHE ECONOMIQUE ET SES APPLICATIONS

Document de travail (Docweb) no 1708

\title{
Retirement and Unexpected Health Shocks
}

Bénédicte H. Apouey

Cahit Guven

Claudia Senik 


\title{
Retirement and Unexpected Health Shocks ${ }^{1}$
}

\author{
Bénédicte H. Apouey ${ }^{2}$, Cahit Guven ${ }^{3}$, Claudia Senik ${ }^{4}$
}

\begin{abstract}
Do people form correct expectations about the impact of retirement on their health? This paper looks at unexpected health shocks that hit people after they retire. Using data from the Household, Income and Labour Dynamics in Australia survey (waves 2001-2014), we construct measures of unexpected health shocks for each year, using information on respondents' views about the expected and past evolution of their health status. By definition, unexpected health shocks are immune to the problem of reverse causality (running from health condition to retirement). Our findings indicate that retirement increases the likelihood of positive health shocks and decreases the probability of negative shocks for men, with no clear results for women. These shocks are mirrored by variations in life satisfaction of the same nature (e.g. increased life satisfaction in case of unexpected positive health shocks). Other indicators of mental and physical health taken from the SF-36 vary in the same way, i.e. improve unexpectedly after retirement for men. These findings suggest that, at least in the case of men, people's desire to retire may not be based on perfectly correct expectations about the impact of this move, but is aligned with its actual consequence: retirement exerts a positive causal impact on health.
\end{abstract}

Keywords: Australia, HILDA, Health, Retirement, Health Shocks, Life Satisfaction.

\section{Retraite et chocs de santé non-anticipés}

\begin{abstract}
Les individus anticipent-ils bien l'impact de leur départ à la retraite sur leur santé ? Cet article s'intéresse aux chocs de santé non-anticipés qui touchent les individus qui prennent leur retraite. En utilisant les données de l'enquête « Household, Income and Labour Dynamics in Australia » (entre 2001 et 2014), nous construisons des mesures de chocs de santé non-anticipés, en combinant des informations sur l'évolution anticipée et réalisée de l'état de santé des individus. Par construction, les chocs de santé non-anticipés ne peuvent pas être sujets à des problèmes de causalité inverse (c'est-àdire de causalité allant de la santé vers la décision de prendre sa retraite). Nos résultats montrent que, pour les hommes, le départ à la retraite accroît la probabilité de connaître des chocs de santé positifs et réduit la probabilité de subir des chocs de santé négatifs (pour les femmes, nos résultats ne sont pas clairs). Ces chocs engendrent des variations de satisfaction dans la vie (par exemple on observe une amélioration de la satisfaction dans la vie lors de chocs de santé positifs). Nous obtenons des résultats cohérents lorsque nous utilisons d'autres mesures de santé mentale et physique, dérivées du SF-36. Ces résultats suggèrent que, pour les hommes du moins, le désir de prendre sa retraite n'est peut-être pas fondé sur des anticipations parfaitement correctes concernant l'effet du départ à la retraite, mais est cohérent avec ses conséquences : la retraite exerce un effet positif sur la santé.
\end{abstract}

Mots-clefs : Australie, HILDA, Santé, Retraite, Chocs de santé, Satisfaction.

\footnotetext{
${ }^{1}$ This paper uses data from the Household, income, and Labour Dynamics in Australia (HILDA) survey. The HILDA project was initiated and is funded by the Australian Government Department of Social Sciences (DSS) and is managed by the Melbourne Institute of applied Economic and Social Research (Melbourne Institute). The findings and views reported in this paper, however, are those of the authors and should not be attributed to either DSS or the Melbourne Institute. We thank F. Bourguignon, R. P. Ellis, P.-Y. Geoffard, I. Jelovac, J.-F. Laslier, Q. Roquebert and L. Rochaix for useful comments. We thank CEPREMAP (Well-Being Observatory) and the French National Research Agency, through the program Investissements d'Avenir, ANR-10-LABX-93-01, for financial support.

${ }^{2}$ Paris School of Economics - CNRS

${ }^{3}$ Deakin University, Department of Economics

${ }^{4}$ Université Paris-Sorbonne and Paris School of Economics
} 


\section{Introduction}

Workers generally plan to retire as soon as they are entitled to leave with full pension, depending on the legal provisions in vigor. They demonstrate massively against any attempt to postpone the legal time of retirement. Obviously, this behavior is based on the expectation that retirement will be a source of greater wellbeing. But is it actually the case? Or do they underestimate the risk of loss of purpose and socialization that come with withdrawal from the labor market? This paper tries to elucidate this point. It asks whether people's expectations about the effect of retirement are correct or misleading. Behavioral economics have forcefully illustrated the possibility of such incorrect expectations. Our study measures the unintended consequences of retirement on people's health. By doing so, it avoids confusing the cause and the consequence of retirement, i.e. the risk of reverse causation, whereby people whose health is deteriorating, or who expect it to do so, choose to retire earlier.

A substantial literature has tried to measure the impact of retirement on general, physical and mental health, life satisfaction and lifestyles. The general prior is that retirement should make people happier and healthier, given the deleterious impact of work tiredness on aging workers, not to mention the case of strenuous work. However, retirement may also have a detrimental effect on wellbeing due to the state of anomia that sometimes accompanies the disaffiliation of former workers, if their job used to be their main locus of socialization. Empirically, identifying the causal effect of retirement on health is not straightforward. This is because people's current and expected health state certainly influences their retirement decision, as shown by Siddiqui (1997), Dwyer and Mitchell (1999), McGarry (2004), Au et al. (2005), Cai and Kalb (2006) and Disney et al. (2006). Identically, concerning the relationship between health and unemployment, Böckerman and Ilmakunnas (2009) have shown that, in Finland, workers in poor health condition self-select into unemployment, but unemployment itself does 
not deteriorate workers' self-assessed health. Moreover, both retirement and health may depend on unobserved confounding factors, such as time preferences.

To account for such endogeneity problems, existing studies have used econometric methods based on instrumentation techniques and individual fixed effects. The most widely used instrumentation strategy consists in exploiting the discontinuity in countries' legislation concerning the full-pension eligibility age. Papers have used data from the U.S. Health and Retirement Survey (HRS), the European Survey on Health, Ageing and Retirement in Europe (SHARE), the European Survey on Income and Living Conditions (SILC) and some country specific surveys, such as Household, Income and Labour Dynamics in Australia (HILDA). Surprisingly, although they share this same method and often the same data, their findings are mixed.

Several papers have documented the negative impact of retirement on health outcomes. For instance, using the U.S. HRS, Dave et al. (2008) showed that health, as measured by general self-assessed health, mobility, difficulty with daily activity, specific physical conditions and depression, deteriorates after retirement. The literature also consistently indicates that retirement has a negative effect on body weight for men who retire from strenuous jobs (but not for women or workers in sedentary jobs), either in the U.S. (Goldman et al., 2008) or in Europe (Godard, 2016). Some papers have focused on the effect of retirement on cognitive abilities. Bonsang et al. (2012) claimed that retirement has a negative impact on cognitive functioning using HRS. Their result was comforted by Mazzonna and Peracchi (2012) who found that cognitive abilities decline at a higher pace after retirement, using SHARE. However, it was challenged by Coe et al. (2012), who used the same HRS data. Finally, Behncke (2012) used the English Longitudinal Study of Ageing (ELSA) and found that retirement significantly increases the risk of being diagnosed with a chronic condition, such as a cardiovascular disease and cancer, as well as other risk factors (e.g. BMI, cholesterol, blood 
pressure); it also worsens self-assessed health.

However, another series of studies have uncovered a positive impact of retirement on wellbeing in different countries. Shai (2015) used data from three Israeli sources and shows that the postponement of retirement due to the increase in the mandatory retirement age for men in 2004 was associated with a worsening of health, especially among less-educated workers. Similarly, Zhu (2016) showed that women's health suffered from the increase in the retirement age eligibility, induced by the Australian Age Pension Policy, using HILDA. Both retirement status and retirement duration seem to exert a positive impact on self-assessed health status, as well as on SF-36 mental and physical components. Moreover, retirement status and duration also increased their regular physical activity and decreased the probability of smoking. Mavromaras et al. (2013) and Atalay and Barrett (2014) reached similar conclusions based on Australian data. Other authors provide similar evidence based on HRS (Insler, 2014), SHARE (Coe and Zamarro, 2011), SILC (Hessel, 2016) and German panel data (Eibich, 2015). In the latter paper, the channel is the relief from work-related stress and strain and the increase in sleep duration and in physical activity. Hallberg et al. (2015) reached the same conclusion using a reform in the retirement age of military officers in Sweden. Finally, some papers have released more ambiguous results, with positive impact of retirement on mental health and less clear effects on physical health (Johnston and Lee, 2009).

The different conclusions reached by these studies may be due to differences in econometric specification, control variables and countries of interest, as shown by the exhaustive study by Motegi et al. (2016). In addition, it is also well known that the take-up of reforms is not uniform across individuals. In the case of retirement, there remains some leeway in the manner people react to the change in the legal full-pension retirement age. Some people may abide by the increase in the legal retirement age, with a clear understanding that this will be detrimental (or beneficial) to their health. Other may overlook this phenomenon. Other people 
may decide to retire earlier, even if this comes at the cost of a lower pension. Because of this residual freedom of choice, the usual instrumentation strategy may not capture the exact effect of retirement on wellbeing and may still be fraught with reverse causation bias. Instead, looking at unexpected health shocks allows ruling out this risk.

We thus depart from the literature and analyze the impact of retirement on unexpected health shocks. We use the SF-36 questionnaire contained in HILDA panel survey. At each wave of the survey, people are asked to assess their health evolution over the past year, as well as their expected health change in the future. Combining the answers to these two questions, we construct a measure of unexpected health shocks, distinguishing positive and negative unexpected shocks. We estimate the association between retirement and positive / negative health shocks, for different segments of the population. To account for unobserved heterogeneity, we include individual fixed effects in our regression models.

As mentioned earlier, several papers have used the same HILDA survey before us to enquire about the effect of retirement on health. However, they did not make use of the information about health expectations. They also used a different definition of retirement. In Zhu (2016) for instance, retirement is defined as not being in the labor force, whereas we consider a person as retired if he/she does not work and declares to be completely retired.

Our findings indicate that retirement - both being retired and retiring - increases the likelihood of positive health shocks and decreases the likelihood of negative health shocks for men. The results concerning women are unclear. We also use another piece of information coming from the SF-36 questionnaire. For men, retirement comes with unexpected improvement in physical health measures such as physical functioning, role functioning/physical, bodily pain and general health measures. It also improves measures of mental health such as vitality, social functioning and role functioning/emotional. For women, again, the impact is much less 
straightforward. Finally, we look at the impact of health shocks on life satisfaction. It turns out that the level of health and health shocks are correlated with the level of current life satisfaction declared by retired people (i.e. unexpected negative health shocks significantly reduce life satisfaction, while unexpected positive health shocks significantly improve life satisfaction, for both men and women).

The lessons of these findings are that retirement does have an impact on people's health and this impact is asymmetric across gender: it is globally positive for men and unclear for women. The possibility that people misperceive the consequence of retirement on their wellbeing bears important implications in terms of policy. For example, a popular recommendation aimed at taking into account the heterogeneity in people's preferences, is to offer them the choice of when to retire, while incentivizing them to remain in activity for a longer time. This policy rests on the assumption that people take their decisions on the basis of correct expectations. Our results suggest that men's expectations about the evolution of their wellbeing after retirement are likely to be too pessimistic.

The paper proceeds as follows. Section 2 describes the HILDA data. Section 3 presents the empirical model and the estimation strategy. Section 4 discusses the findings. Section 5 concludes.

\section{Data}

The HILDA survey

We use data from the Household, Income and Labour Dynamics in Australia (HILDA) survey including rounds 1 to 14 , covering the period 2001-2014. HILDA surveys all adults (aged over 15) within each household annually since 2001 and collects an extensive amount of 
information regarding economic wellbeing, health status, labor market dynamics and family dynamics. Our sample contains individuals who were aged 50 to 75 between 2001 and 2014 .

\section{Expected and unexpected changes in overall health}

We use information from the 36-item Short Form Health Survey (SF-36) to measure expected and unexpected changes in overall health. The SF-36 is a patient-reporting outcome measure that quantifies health status. The survey contains 36 questions, 35 of which are used to create eight scores that capture eight health concepts: physical functioning (PF), role functioning/physical (RP), bodily pain (BP), general health perceptions (GH), vitality (VT), social role functioning (SF), mental health $(\mathrm{MH})$ and role functioning/emotional (RE). In HILDA, the eight scores are provided on a 0-100 scale. The remaining question asks about overall health transition (see below). Some scores are more closely related to physical health (PF, RP, BP and GH) while the remaining ones are more closely linked to mental wellbeing (VT, SF, MH and RE). We will make use of this dividing line.

To construct our main variables of interest, we employ two questions about self-reported health from the SF-36. First, a question about overall health expectations: "How true of false is [each of] the following statement for you? I expect my health to get worse." Respondents have to tick one out the following categories: "Definitely true," "Mostly true," "Don't know," "Mostly false" and "Definitely false" (the name of the variable is gh11c; this question on expectations is used to construct the GH score, together with four other questions). Using these pieces of information, we recode the variable into three categories: True, Don't know and False. The question does not explicitly mention any time horizon; however it comes after a series of questions about the following year, which might induce respondents to think about the evolution of their health during the course of the next year. 
Second, we measure the actual evolution of respondents' health in the past year using the following question: "Compared to one year ago, how would you rate your health in general now?" The proposed response categories are the following: "Much better now than one year ago," "Somewhat better than one year ago," "About the same as one year ago," "Somewhat worse than one year ago" and "Much worse than one year ago" (the name of the variable is ghrht; this question about health transition is not used to construct any of the aforementioned eight scales). Using these pieces of information, we recode the variable into three categories: Worse, Same and Better.

We create the outcome variables in the way indicated in Table 1 . We henceforth compare the expected health evolution reported by respondents in $\mathrm{t}-1$, with their actual health transition between $\mathrm{t}-1$ and $\mathrm{t}$, as reported in $\mathrm{t}$.

\section{Expected and unexpected changes in the eight SF-36 scores}

We also use the SF-36 to construct additional variables. For each of the eight scores, we calculate individual health evolution between $\mathrm{t}-1$ and $\mathrm{t}$ and create a variable that indicates whether health worsened, remained stable or improved over time. Ideally, we would like to combine this information about people's ex post health evolution with their ex ante expectations for the same eight scores. However, expectations are only elicited for overall health (see above). We thus combine information about expected overall health in the future as reported in (t-1) with information about the evolution in the eight scores (between $\mathrm{t}-1$ and $\mathrm{t}$ ) in order to construct additional shocks variables. Admittedly, these measures of shocks are imperfect; we thus consider the results as a robustness exercise. 


\section{Life satisfaction}

Our measure of life satisfaction is based on the classic question: "How satisfied are you with your life?" with a scale ranging from 0 ("Totally dissatisfied") to 10 ("Totally satisfied"). Average life satisfaction reaches 7.95 for males and 8.01 for females. This question is routinely used in large surveys to measure subjective wellbeing, e.g. by Gallup, the World Values Survey, the European Social Survey, the British ONS and the OECD, for instance.

\section{Retirement and labor market status}

Several definitions of retirement have been used in the literature. For instance, Eibich (2015), using the GSOEP, assumes that an individual is "retired" if she reports that she is retired and that she does not work, even part-time, while Zhu (2016), using HILDA, considers that a person is retired if she reports that she is not in the labor force.

Here, we focus essentially on "complete retirement." Specifically, the data indicate whether individuals are employed, unemployed or not in the labor force (NLF). In addition, individuals who are over 45 years and who are not working are asked: "Have you retired (completely) from the workforce?" The response categories are the following: "Yes," "No" and "Never in the workforce." We consider those who answered "Yes" to this question as retired people. This question is asked in every wave except in 2003, 2004, 2007 and 2011. In order to avoid losing observations in 2003 and 2004, we assume that if an individual is completely retired in 2002 and in 2005, then he is also completely retired in 2003 and 2004. Similarly, we assume that if she is not completely retired in 2002 and 2005, then she is also not completely retired in 2003 and 2004 . We proceed in the exact same way for 2007 and 2011. By combining the answers to these two questions, we create a categorical variable indicating whether the individual reports being (i) employed (reference category), (ii) unemployed or NLF and not completely retired, (iii) unemployed or NLF and completely 
retired and (iv) unemployed or NLF and never in the workforce. We are interested in the association between complete retirement and health shocks.

We also create a series of dummies capturing labor market transitions between two consecutive years. Some transitions are rare and are thus combined into an "Other cases" category. The categories are the transition variable are the following: (i) remaining employed between $\mathrm{t}-1$ and $\mathrm{t}$ (reference category); (ii) employed at $\mathrm{t}-1$ and not completely retired at $\mathrm{t}$, (iii) employed at $\mathrm{t}-1$ and completely retired at $\mathrm{t}$, (iv) not completely retired at $\mathrm{t}-1$ and employed at $\mathrm{t}$, (v) remaining not completely retired between $\mathrm{t}-1$ and $\mathrm{t}$, (vi) not completely retired at $\mathrm{t}-1$ and completely retired at $\mathrm{t}$, (vii) completely retired at $\mathrm{t}-1$ and employed at $\mathrm{t}$, (viii) completely retired at $\mathrm{t}-1$ and not completely retired at $\mathrm{t}$, (ix) remaining completely retired between $\mathrm{t}-1$ and $\mathrm{t}$ and (x) other cases. We focus on the association between transition to complete retirement and health shocks.

In our regressions, individuals who are employed or who remain employed over consecutive years serve as the reference category.

Surprisingly, approximately 750 individuals (corresponding to 5790 observations) retire several times, or come back to the labor force after retiring. We check that excluding these individuals from our sample does not significantly influence our results.

\section{Descriptive statistics}

Table 1 provides summary statistics for the entire sample (retired or not). Over one third of the sample does not have a precise idea of how their health will change in the coming year; about one quarter expects a worsening and over one third expects an improvement or no change. Women are more optimistic than men. Concerning the actual evolution of their health, a large majority (two thirds) of male respondents acknowledge no change in their 
health, about $10 \%$ report an improvement and $17 \%$ a worsening. Women less often report no change. As a result, concerning the difference between expectations and actual realizations, about $9 \%$ of males experience an unexpected negative shock and $24 \%$ experience an unexpected positive shock. For women, these figures are respectively $11 \%$ and $18 \%$.

Around $58 \%$ of males and $45 \%$ of females are employed, and $34 \%$ of males and $44 \%$ of females are completely retired. $71 \%$ of males and $61 \%$ of females are married. The average age in the sample is 60 years for males and 61 years for females; the average number of years of education is 12 years for males and 11 years for females.

Table 2 presents descriptive statistics of health outcomes by gender and retirement status. $10 \%$ of retired men experience an unexpected negative health shock, and $26 \%$ an unexpected positive shock. For women, these figures are $12 \%$ and $19 \%$. Hence, men experience less negative shocks and more positive shocks upon retirement as compared to women. The remainder of the sample forms correct expectations (either positive or negative)

[Insert Table 2 here]

\section{Empirical Model}

To analyze the potential effects of retirement on health shocks, we estimate the following baseline model using OLS-Fixed Effects:

$\mathrm{Y}_{\mathrm{i},(\mathrm{t}-1, \mathrm{t})}=\beta \cdot \mathrm{LMS}_{\mathrm{i},(\mathrm{t}-1, \mathrm{t})}+\mathrm{X}_{\mathrm{i}, \mathrm{t}} \delta+\alpha_{\mathrm{i}}+\varepsilon_{\mathrm{i}, \mathrm{t}-1, \mathrm{t}}$

$\mathrm{Y}_{\mathrm{i}(\mathrm{t}-1, \mathrm{t})}$ is the outcome variable of interest. In most specifications, it is a dummy variable indicating the nature of the health shock experienced by the individual between $\mathrm{t}-1$ and $\mathrm{t}$. LMS consists of indicators of labor market status (not completely retired, completely retired, never in the workforce) reported in year $t$, or of measures of labor market transitions between t-1 and t. Note that given that we include individual fixed effects, the effect of "never in 
workforce" should not be identified, but a small fraction of respondents do not consistently report that they have never been in the workforce (measurement error). If an individual becomes completely retired between $t-1$ and $t$, then $\beta$ will capture the unanticipated effect of retirement on his health. Vector $\mathrm{X}_{\mathrm{i}, \mathrm{t}}$ includes the following control variables: age, marital status, family size, education, the logarithm of household income and year dummies. $\alpha_{i}$ represents individual fixed effects.

We also enlarge the window of analysis and look at the dynamics of health shocks prior and after retirement, using the following regression:

$$
\begin{aligned}
Y_{i,(t-1, t)} & \beta_{-4} \cdot R_{-4, i, t}+\beta_{-3} \cdot R_{-3, i, t}+\beta_{-2 \cdot} \cdot R_{-2, i, t}+\beta_{-1} \cdot R_{-1, i, t} \\
& +\beta_{0} \cdot R_{0, i, t}+\beta_{+1} \cdot R_{+1, i, t}+\beta_{+2} \cdot R_{+2, i, t}+\beta_{+3} \cdot R_{+3, i, t}+\beta_{+4 \cdot} R_{+4, i, t}+\beta_{+5 .} \cdot R_{+5, i, t} \\
& +X_{i, t .} \delta+\alpha_{i}+\varepsilon_{i, t}
\end{aligned}
$$

To pick up anticipation, we split the group of people who are not completely retired into five groups: individuals who will enter retirement in the next 5 years or more, in the next 3-4 years, in the next 2-3 years, in the next 1-2 years and in the next $0-1$ year. The corresponding dummy variables are named as $\mathrm{R}_{-5}, \mathrm{R}_{-4}, \mathrm{R}_{-3}, \mathrm{R}_{-2}$ and $\mathrm{R}_{-1}$. The omitted category comprises those who will enter retirement in the next 5 years or more (R-5). To estimate adaptation, we divide the retired into six groups: those who have been retired for $0-1$ years, $1-2$ years, and so on up to those who have been retired for 5 years or more. The corresponding dummy variables are $\mathrm{R}_{0}, \mathrm{R}_{+1}, \mathrm{R}_{+2}, \mathrm{R}_{+3}, \mathrm{R}_{+4}$ and $\mathrm{R}_{+5}$.

Equation (2) can only be estimated for a smaller sample than equation (1) due to sometimes missing information (since the data do not always allow to identify the year of retirement.). Moreover, we restrict the regression sample to individuals who transition (from being "employed," "not completely retired" or "never in the workforce") to complete retirement at 
some point during the survey. In particular, we obviously cannot use individuals who are already retired in the first survey year.

Given the differences in labor market histories, the models are estimated for males and females separately. In all specifications models, we compute robust standard errors at the person level.

\section{Main results}

We first look at health expectations and transitions separately. Table 3 shows that men who are retired in year $t$ more often expected their health to deteriorate and less often expected an improvement, as compared to when they are employed (columns (1)-(3)). De facto, being retired rather than employed increases the likelihood of experiencing a health improvement (columns (4)-(6)).

For women, the picture is different, as the health expectations of women who are retired do not differ from their expectations when they are employed. However, women endure a worsening of their health when they are retired.

In Table 4, we estimate equation (1) using labor market transitions to retirement. Men who remain retired or who become retired more often experience a (self-declared) improvement in their health (column (6)), although they expect it less often (column (3)). There is no remarkable result for women. Accordingly, Table 5 shows that men experience more positive health shocks upon retirement, whereas there is no effect for women.

Table A1 in the Appendix details the channel of these shocks. For men, the result is driven both by men who wrongly expect a worsening of their health while their health remains the same (column (4)) and by men who do not form any expectation and acknowledge an 
improvement in their health (column (6)). Table A1 also provides some evidence that retired women endure less unexpected positive shocks than employed women (column (4)).

As noticed, a number of individuals retire several times, or come back to the labor force after retiring. We re-estimate the main model excluding these individuals and obtain similar results (see Appendix, Table A2).

These findings are illustrated by event studies represented in Figure 1, which displays estimates of expectations, transitions and health shocks following equation (2) on the sample of people who retire at some point during the survey. Each point then represents the value of the coefficient associated with a specific year in the regression of health shock (see equation (2) above). These coefficients are estimated in reference to the situation where people will retire in more than five years (on the horizontal axis, the time line is set to zero five years before retirement). For men, the figure suggests that, as they get closer to retirement, men are increasingly likely to experience positive shocks (green line). The coefficient becomes statistically significant upon the year of retirement and remains positive thereafter, with a clear upward trend. For women, the situation is different: we do not observe any trend in health shocks around the time of retirement.

Are these findings specific to retirement? To enquire, we ran the same type of event studies to observe the lags and leads of health shocks around the time of an unemployment spell. As shown by Figure 2, there is no clear trend for males. This does not mean that men's health does not change during such episodes; simply, unemployment spells do not increase the likelihood of unexpected health changes (there is some evidence that men experience less negative shocks three years after an unemployment spell though). Hence, the pattern that we uncovered around the time of retirement is not replicated for unemployment spells. For women, unemployment increases the chance of positive shocks. 
We also explored the lags and leads of health shocks around the time of other life events, such as marriage, separation/divorce and widowhood (see Figure A1 in Appendix). Men experience less positive shocks around the time of marriage, and more positive shocks around separation. There is no evidence that widowhood be associated with shocks for men. For women, both marriage and widowhood increase the probability of negative shocks. There is no (statistically significant) pattern of any type of unanticipated health evolution for women around the time of separation.

A natural question is whether the effect of retirement depends on the type of occupation, in particular, across blue collar versus white collar workers. The impact could also depend on whether the person who retires has a partner, and whether this partner is herself retired or not. As it turns out, although these conditions are indeed correlated with the level of health of respondents, they are not associated with health shocks, i.e. with unexpected changes in one's health status (these results are not reported for space reasons).

Retirement could have a diverse impact on physical versus mental health. For instance, it could relieve workers from the tiredness of long workdays and strenuous work, but leave them in disarray for lack of social ties. To enquire, we looked at more detailed measures of self-declared physical and mental health that are available in the SF-36 questionnaire, included in HILDA at each wave. We looked at the impact of retirement on unexpected health evolutions, as explained in Section 2. It turns out that retirement has an unexpected beneficial impact on all indicators of physical health for men, i.e. physical functioning, role functioning (physical), bodily pain and general health, as well as on vitality, social functioning and role functioning (emotional) (Table 6). For women, the results are less clear and not straightforward (Table 7). Retirement triggers more unexpected negative shocks in role functioning (physical) and role functioning (emotional), less negative shocks in vitality and 
more positive shocks in physical functioning. However, for women, the correlations are statistically insignificant for most measures of mental and physical health.

\section{Sensitivity analysis and additional results}

\section{Additional controls}

As documented in the previous literature, some people retire because of illness. To account for this, we re-estimated the main model, controlling for lagged health. Here health status is captured by self-assessed health (SAH): "In general, would you your health is: Excellent, Very good, Good, Fair, Poor?" The previous findings remain unchanged. For men, even controlling for previous health status, complete retirement is associated with positive health shocks. For females, there is some evidence that retirement is negatively associated with positive shocks (Table A3).

\section{Attrition}

Attrition may affect the representativeness of our sample and lead to biased estimates of the impact of retirement. To adjust for attrition, we re-estimated our main model using longitudinal weights. The findings are essentially unchanged: retired men experience more unexpected positive shocks, whereas retired women, if anything endure less positive health shocks (Table A4).

\section{Shocks and life satisfaction}

Finally, Table A5 illustrates the correlation between unexpected shocks and life satisfaction. The correlations between health transitions and life satisfaction are unsurprising. Moreover, people whose health has changed for the better (unexpectedly) are more satisfied with their life in any given year. 
Interpretation of the asymmetry between genders

The uncovered asymmetry between men and women is certainly due to the different work experience of women over their life cycle, i.e. more frequent interruptions and withdrawals from the labor market, due to maternity and family life. Because of this unequal participation in the labor force, many studies focus on men, who form a more homogenous group and for whom the notion of retirement is more clear-cut. Concerning the impact of retirement on women, there are several possible interpretations, which we are unable to fully investigate in this paper. The first one is that women may be more able to anticipate the evolution of their health than men. Alternatively, it could be the case that women, due to the greater diversity of their domains of investment, are less sensitive to the discontinuation of their work ties. For this reason, they may be less anxious about losing their professional activity, hence form less negative expectations about their future wellbeing, on the eve of retirement. However, these conjectures remain avenues for future research.

\section{Conclusion}

This paper examines the impact of retirement on expected and unexpected health changes, using longitudinal data on elder Australian residents, from the 2001-2014 HILDA panel survey. We are interested in health shocks, as measured by the difference between expected health status (reported in $\mathrm{t}-1$ ) and health transition (reported in $\mathrm{t}$ ). This is because evaluating the impact of retirement on health is not straightforward. Workers could retire because their health is deteriorating and they anticipate that this degradation will worsen, rendering work increasingly difficult. The usual route followed by social scientists, in order to overcome this reverse causation problem, consists in exploiting reforms of the legal age of retirement and looking at the impact of an additional year of activity on the workers touched by the reform. However, this method also has its limits, because of possible non-compliance and because of 
the specific frustration that workers hit by the reform can feel. Moreover, the conclusions of these studies are not univocal. Some point to the beneficial effect of retirement on health while others uncover a detrimental effect. We use another route, which consists in identifying directly the unanticipated part of the variation in health that occurs upon retirement. This exempts us from the obligation of instrumenting the retirement decision, as by definition, a health shock is unexpected and exogenous. We observe a rise in positive health shocks for men who retire. This shock is driven by the more negative expectations of men upon retirement and the more positive evolution of their health after retirement. These positive health shocks are confirmed by other measures of mental and physical well-being measured by SF-36 measures, as well as self-declared life satisfaction. Such positive shocks do not happen upon unemployment spells, for instance. Concerning women, we do not uncover any type of unexpected impact of retirement. If anything, women who move to a situation where they are "not completely retired" suffer negative health shocks. We also failed to uncover any difference in the impact of retirement across occupations or marital status of workers.

Due to the increase in the length of life expectancy, developed countries have recently had to reform their retirement systems and postpone the age of retirement. This paper shows that such reform, although necessary, come at a cost in terms of wellbeing and health, especially for older male workers. 


\section{Acknowledgements}

This paper uses data from the Household, income, and Labour Dynamics in Australia (HILDA) survey. The HILDA project was initiated and is funded by the Australian Government Department of Social Sciences (DSS) and is managed by the Melbourne Institute of applied Economic and Social Research (Melbourne Institute). The findings and views reported in this paper, however, are those of the authors and should not be attributed to either DSS or the Melbourne Institute. We thank F. Bourguignon, R. P. Ellis, P.-Y. Geoffard, I. Jelovac, J.-F. Laslier, Q. Roquebert and L. Rochaix for useful comments.

We thank CEPREMAP (Well-Being Observatory) and the French National Research Agency, through the program Investissements d'Avenir, ANR-10-LABX-93-01, for financial support. 


\section{References}

Atalay, K., \& Barrett, G. F. (2014). The causal effect of retirement on health: New evidence from Australian pension reform. Economics Letters, 125(3), 392-395.

Au, D. W. H., Crossley, T. F., \& Schellhorn, M. (2005). The effect of health changes and long-term health on the work activity of older Canadians. Health Economics, 14(10), 9991018.

Behncke, S. (2012). Does retirement trigger ill health? Health Economics, 21(3): 282-300.

Böckerman, P. \& Ilmakunnas, P. (2009). Unemployment and self-assessed health: Evidence form panel data. Health Economics, 18(2): 161-179.

Bonsang, E., Adam, S., \& Perelman, S. (2012). Does retirement affect cognitive functioning? Journal of Health Economics, 31(3): 490-501.

Cai, L., \& Kalb, G. (2006). Health status and labour force participation: Evidence from Australia. Health Economics, 15(3), 241-261.

Coe, N. B., von Gaudecker, H. M., Lindeboom, M., \& Maurer, J. (2012). The effect of retirement on cognitive functioning. Health Economics, 21(8), 913-927.

Coe, N. B., \& Zamarro, G. (2011). Retirement effects on health in Europe. Journal of Health Economics, 30(1), 77-86.

Dave, D., Rashad, I., \& Spasojevic, J. (2008). The effects of retirement on physical and mental health outcomes. Southern Economic Journal, 75(2): 497-523.

Disney, R., Emmerson, C., \& Wakefield, M. (2006). Ill health and retirement in Britain: A panel data-based analysis. Journal of Health Economics, 25(4), 621-649.

Dwyer, D. S. \& Mitchell, O. S. (1999). Health problems as determinants of retirement: Are self-rated measures endogenous? Journal of Health Economics, 18(2): 173-193.

Eibich, P. (2015). Understanding the effect of retirement on health: Mechanisms and heterogeneity. Journal of Health Economics, 43: 1-12.

Godard, M. (2016). Gaining weight through retirement? Results from the SHARE survey. Journal of Health Economics, 45: 27-46.

Goldman, D., Lakdawalla, D., \& Zheng, Y. (2008). Retirement and weight, mimeo. Available at: http://www.aeaweb.org/assa/2009/retrieve.php?pdfid=219.

Hallberg, D., Johansson, P., \& Josephson, M. (2015). Is an early retirement offer good for your health? Quasi-experimental evidence from the army. Journal of Health Economics, 44, 274-285. 
Hessel, P. (2016). Does retirement (really) lead to worse health among European men and women across all educational levels? Social Science \& Medicine, 151, 19-26.

Insler, M. (2014). The health consequences of retirement. Journal of Human Resources, 49(1), 195-233.

Johnston, D. W., \& Lee, W. S. (2009). Retiring to the good life? The short-term effects of retirement on health. Economics Letters, 103(1), 8-11.

Mavromaras, K., Richardson, S., \& Zhu, R. (2013). Age pension, age eligibility, retirement and health outcomes in Australia. National Institute of Labour Studies WP, (201).

Mazzonna, F. \& Peracchi, F. (2012). Ageing, cognitive abilities and retirement. European Economic Review, 56(4): 691-710.

McGarry, K. (2004). Health and retirement do changes in health affect retirement expectations? Journal of Human Resources, 39(3), 624-648.

Motegi, H., Nishimura, Y., \& Oikawa, M. (2016). What explains the difference in the effect of retirement on health? Evidence from Global Aging Data. MRPA Working Paper no. 73963.

Shai, O. Is retirement good for men's health? Evidence using a change in the retirement age in Israel. Mimeo. Available at:

http://www.iza.org/conference_files/SUMS_2015/shai_o21753.pdf

Siddiqui, S. (1997). The impact of health on retirement behaviour: Empirical evidence from West Germany. Health Economics, 6(4), 425-438.

Zhu, R. (2016). Retirement and its consequences for women's health in Australia. Social Science \& Medicine, 163: 117-125. 


\section{TABLES}

Table 1. Descriptive statistics, for ages 50-75

\begin{tabular}{|c|c|c|c|c|}
\hline Variables & $\begin{array}{l}\text { Males } \\
\text { Proportion } \\
(\%) \\
\text { or mean } \\
\end{array}$ & $\begin{array}{c}\text { (Standard } \\
\text { error) }\end{array}$ & $\begin{array}{l}\text { Females } \\
\text { Proportion } \\
(\%) \\
\text { or mean } \\
\end{array}$ & $\begin{array}{l}\text { (Standard } \\
\text { error) }\end{array}$ \\
\hline $\begin{array}{l}\text { Overall health expectations } \\
\text { Expects worse health }(\mathrm{t}-1) \\
\text { Doesn't know whether health will get worse (t-1) } \\
\text { Expects same or better health (t-1) }\end{array}$ & $\begin{array}{l}29.55 \% \\
36.52 \% \\
33.93 \% \\
\end{array}$ & & $\begin{array}{l}21.71 \% \\
37.96 \% \\
40.33 \% \\
\end{array}$ & \\
\hline $\begin{array}{l}\text { Overall health transitions } \\
\text { Health is worse }(t) \\
\text { Health is the same }(t) \\
\text { Health is better }(t)\end{array}$ & $\begin{array}{l}17.27 \% \\
72.70 \% \\
10.03 \% \\
\end{array}$ & & $\begin{array}{l}19.22 \% \\
67.47 \% \\
13.31 \% \\
\end{array}$ & \\
\hline $\begin{array}{l}\text { Unexpected shocks for overall health and other cases } \\
\text { Unexpected negative } \\
\text { Doesn't know whether health will get worse (t-1) } \\
\text { \& Health is worse }(\mathrm{t}) \\
\text { Expects same or better health }(\mathrm{t}-1) \\
\& \text { Health is worse }(\mathrm{t})\end{array}$ & $\begin{array}{l}8.64 \% \\
5.76 \% \\
2.88 \%\end{array}$ & & $\begin{array}{l}11.09 \% \\
7.19 \% \\
3.90 \%\end{array}$ & \\
\hline $\begin{array}{l}\text { Unexpected same: Doesn't know whether health will get worse (t-1) } \\
\qquad \text { \& Health is the same }(\mathrm{t})\end{array}$ & $27.25 \%$ & & $26.09 \%$ & \\
\hline $\begin{array}{l}\text { Unexpected positive } \\
\text { Expects worse health }(\mathrm{t}-1) \text { \& Health is the same }(\mathrm{t}) \\
\text { Expects worse health }(\mathrm{t}-1) \text { \& Health is better }(\mathrm{t}) \\
\text { Doesn't know whether health will get worse }(\mathrm{t}-1) \\
\text { \& Health is better }(\mathrm{t})\end{array}$ & $\begin{array}{c}24.35 \% \\
18.86 \% \\
1.99 \% \\
3.50 \%\end{array}$ & & $\begin{array}{c}17.97 \% \\
11.32 \% \\
1.99 \% \\
4.67 \%\end{array}$ & \\
\hline Expected worse: Expects worse health (t-1) \& Health is worse (t) & $8.63 \%$ & & $8.23 \%$ & \\
\hline Expects same or better health (t-1) \& Health is the same (t) & $27.02 \%$ & & $30.35 \%$ & \\
\hline Expects same or better health $(\mathrm{t}-1)$ \& Health is better $(\mathrm{t})$ & $4.11 \%$ & & $6.27 \%$ & \\
\hline
\end{tabular}

Unexpected shocks for SF-36 scales*

Unexpected shocks for physical functioning

Unexpected negative

$23.33 \%$

$28.31 \%$

Unexpected same

Unexpected positive

Unexpected shocks for role functioning/physical

Unexpected negative

Unexpected same

$21.26 \%$

$20.62 \%$

Unexpected positive

Unexpected shocks for bodily pain

Unexpected negative

Unexpected same

Unexpected positive

Unexpected shocks for general health

Unexpected negative

\section{Unexpected shocks for vitality}

Unexpected negative 
Unexpected shocks for social functioning

Unexpected negative

$15.77 \% \quad 19.85 \%$

Unexpected same

$17.41 \%$

$15.37 \%$

Unexpected positive

Unexpected shocks for mental health

Unexpected negative

$26.38 \% \quad 30.82 \%$

Unexpected same

$7.21 \%$

$6.15 \%$

Unexpected positive

Unexpected shocks for role functioning/emotional

Unexpected negative

$7.27 \%$
$25.47 \%$

Unexpected same

Unexpected positive

$31.90 \%$

$26.10 \%$

Life satisfaction

7.95

(1.51)

8.01

(1.58)

Labor market status

Employed

$57.58 \%$

Not completely retired

$5.22 \%$

$34.28 \%$

Completely retired

$0.04 \%$

Never in the workforce

\section{Control variables}

Age

60.47

Married

$70.88 \%$

60.56

De facto

$8.01 \%$

$12.45 \%$

Separated

$2.48 \%$

Widowed

2.48

12.05

Years of education

4.15

\begin{tabular}{cc} 
& $61.31 \%$ \\
& $6.15 \%$ \\
& $16.74 \%$ \\
& $11.00 \%$ \\
$(1.21)$ & 2.25 \\
$(2.86)$ & 11.49 \\
$(0.77)$ & 4.00 \\
\hline
\end{tabular}

$6.15 \%$

$6.74 \%$

Log (household income+1)

23,799

26,555

Notes. Standard errors for continuous variables are reported in parentheses.

* We construct these shocks variables by combining information on expectations for overall health in the future (reported in t-1) with information on the evolution in the eight SF-36 scores (between t-1 and t). Admittedly, these measures of shocks are imperfect. For space reasons, we do not show descriptive statistics for expected shocks. 
Table 2. Health outcomes by gender and labor market status

\begin{tabular}{|c|c|c|c|c|c|}
\hline \multirow{2}{*}{\multicolumn{2}{|c|}{ Outcomes }} & Males & Males & Females & Females \\
\hline & & $\begin{array}{l}\text { Employed } \\
\text { (t) }\end{array}$ & $\begin{array}{c}\text { Completely } \\
\text { retired } \\
(\mathrm{t})\end{array}$ & $\begin{array}{l}\text { Employed } \\
\text { (t) }\end{array}$ & $\begin{array}{c}\text { Completely } \\
\text { retired } \\
(\mathrm{t})\end{array}$ \\
\hline \multicolumn{2}{|c|}{ Unexpected negative $(t-1, t)$} & $7.40 \%$ & $9.99 \%$ & $9.12 \%$ & $12.09 \%$ \\
\hline & $\begin{array}{l}\text { Doesn't know whether health will get } \\
\text { worse }(t-1) \& \text { Health is worse (t) }\end{array}$ & $4.52 \%$ & $7.35 \%$ & $5.08 \%$ & $8.57 \%$ \\
\hline & $\begin{array}{l}\text { Expects same or better health }(\mathrm{t}-1) \& \\
\text { Health is worse }(\mathrm{t})\end{array}$ & $2.89 \%$ & $2.64 \%$ & $4.04 \%$ & $3.52 \%$ \\
\hline $\begin{array}{l}\text { Unexpected same } \\
(\mathrm{t}-1, \mathrm{t})\end{array}$ & $\begin{array}{l}\text { Doesn't know whether health will get } \\
\text { worse }(\mathrm{t}-1) \text { \& Health is the same }(\mathrm{t})\end{array}$ & $28.05 \%$ & $26.30 \%$ & $25.13 \%$ & $27.49 \%$ \\
\hline \multicolumn{2}{|c|}{ Unexpected positive $(t-1, t)$} & $22.92 \%$ & $26.41 \%$ & $17.13 \%$ & $18.91 \%$ \\
\hline & $\begin{array}{l}\text { Expects worse health }(\mathrm{t}-1) \& \text { Health is } \\
\text { the same }(\mathrm{t})\end{array}$ & $17.76 \%$ & $20.99 \%$ & $10.44 \%$ & $12.61 \%$ \\
\hline & $\begin{array}{l}\text { Expects worse health }(\mathrm{t}-1) \& \text { Health is } \\
\text { better }(\mathrm{t})\end{array}$ & $1.89 \%$ & $1.98 \%$ & $2.07 \%$ & $1.89 \%$ \\
\hline & $\begin{array}{l}\text { Doesn't know whether health will get } \\
\text { worse }(\mathrm{t}-1) \text { \& Health is better }(\mathrm{t})\end{array}$ & $3.26 \%$ & $3.47 \%$ & $4.63 \%$ & $4.42 \%$ \\
\hline $\begin{array}{l}\text { Expected worse } \\
(t-1, t)\end{array}$ & $\begin{array}{l}\text { Expects worse health }(\mathrm{t}-1) \& \text { Health is } \\
\text { worse }(\mathrm{t})\end{array}$ & $4.65 \%$ & $14.98 \%$ & $4.69 \%$ & $11.41 \%$ \\
\hline \multicolumn{2}{|c|}{ Expects same or better health (t-1) \& Health is the same (t) } & $32.13 \%$ & $19.59 \%$ & $36.74 \%$ & $25.24 \%$ \\
\hline \multicolumn{2}{|c|}{ Expects same or better health (t-1) \& Health is better $(\mathrm{t})$} & $4.85 \%$ & $2.74 \%$ & $7.18 \%$ & $4.81 \%$ \\
\hline Total & & $100 \%$ & $100 \%$ & $100 \%$ & $100 \%$ \\
\hline
\end{tabular}


Table 3. Retirement, health expectations and health transitions

\begin{tabular}{|c|c|c|c|c|c|c|}
\hline & $\begin{array}{c}\text { (1) } \\
\text { Expectations }\end{array}$ & $\begin{array}{c}(2) \\
\text { Expectations }\end{array}$ & $\begin{array}{c}\text { (3) } \\
\text { Expectations }\end{array}$ & $\begin{array}{c}(4) \\
\text { Transitions }\end{array}$ & $\begin{array}{c}\text { (5) } \\
\text { Transitions }\end{array}$ & $\begin{array}{c}(6) \\
\text { Transitions }\end{array}$ \\
\hline & $\begin{array}{l}\text { Expects worse } \\
\text { health } \\
(\mathrm{t}-1)\end{array}$ & $\begin{array}{l}\text { Doesn't know whether } \\
\text { health will get worse } \\
(\mathrm{t}-1)\end{array}$ & $\begin{array}{l}\text { Expects same or } \\
\text { better health } \\
(\mathrm{t}-1)\end{array}$ & $\begin{array}{l}\text { Health is } \\
\text { worse } \\
\text { (t) }\end{array}$ & $\begin{array}{l}\text { Health is the } \\
\text { same } \\
\text { (t) }\end{array}$ & $\begin{array}{l}\text { Health is } \\
\text { better } \\
(\mathrm{t})\end{array}$ \\
\hline \multicolumn{7}{|c|}{ Panel A. Males } \\
\hline Employed (t) & Ref & Ref & Ref & Ref & Ref & Ref \\
\hline $\begin{array}{l}\text { Completely } \\
\text { retired (t) }\end{array}$ & $\begin{array}{c}0.034 * * * \\
(0.013)\end{array}$ & $\begin{array}{c}0.000 \\
(0.015)\end{array}$ & $\begin{array}{c}-0.035^{* * * *} \\
(0.013)\end{array}$ & $\begin{array}{c}0.010 \\
(0.011)\end{array}$ & $\begin{array}{c}-0.032 * * \\
(0.013)\end{array}$ & $\begin{array}{c}0.022 * * \\
(0.009)\end{array}$ \\
\hline Observations & 23,799 & 23,799 & 23,799 & 26,555 & 26,555 & 26,555 \\
\hline $\begin{array}{l}\text { Number of } \\
\text { persons }\end{array}$ & 4,047 & 4,047 & 4,047 & 4,434 & 4,434 & 4,434 \\
\hline \multicolumn{7}{|c|}{ Panel B. Females } \\
\hline Employed (t) & Ref & Ref & Ref & Ref & Ref & Ref \\
\hline $\begin{array}{l}\text { Completely } \\
\text { retired }(\mathrm{t})\end{array}$ & $\begin{array}{l}-0.003 \\
(0.010)\end{array}$ & $\begin{array}{c}0.019 \\
(0.013)\end{array}$ & $\begin{array}{l}-0.016 \\
(0.012)\end{array}$ & $\begin{array}{l}0.020 * \\
(0.011)\end{array}$ & $\begin{array}{c}-0.034 * * \\
(0.014)\end{array}$ & $\begin{array}{c}0.014 \\
(0.010)\end{array}$ \\
\hline Observations & 26,195 & 26,195 & 26,195 & 29,290 & 29,290 & 29,290 \\
\hline $\begin{array}{l}\text { Number of } \\
\text { persons }\end{array}$ & 4,398 & 4,398 & 4,398 & 4,803 & 4,803 & 4,803 \\
\hline
\end{tabular}

Notes. Each panel corresponds to a specific regression. Control variables are included: not completely retired (t), never in the workforce ( $t$ ), age, age square, marital status, household size, the number of years of education, the logarithm of household income and year dummies. Robust standard errors in parentheses.

$* * * \mathrm{p}<0.01, * * \mathrm{p}<0.05, * \mathrm{p}<0.1$. 
Table 4. Transition to retirement, health expectations and health transitions

\begin{tabular}{|c|c|c|c|c|c|c|}
\hline & $\begin{array}{c}(1) \\
\text { Expectations }\end{array}$ & $\begin{array}{c}(2) \\
\text { Expectations }\end{array}$ & $\begin{array}{c}\text { (3) } \\
\text { Expectations }\end{array}$ & $\begin{array}{c}(4) \\
\text { Transitions }\end{array}$ & $\begin{array}{c}(5) \\
\text { Transitions }\end{array}$ & $\begin{array}{c}(6) \\
\text { Transitions }\end{array}$ \\
\hline & $\begin{array}{l}\text { Expects worse } \\
\text { health } \\
(\mathrm{t}-1)\end{array}$ & $\begin{array}{c}\text { Doesn't know whether } \\
\text { health will get worse } \\
(\mathrm{t}-1)\end{array}$ & $\begin{array}{l}\text { Expects same or } \\
\text { better health } \\
(\mathrm{t}-1)\end{array}$ & $\begin{array}{l}\text { Health is } \\
\text { worse } \\
(\mathrm{t})\end{array}$ & $\begin{array}{l}\text { Health is the } \\
\text { same } \\
\text { (t) }\end{array}$ & $\begin{array}{l}\text { Health is } \\
\text { better } \\
\text { (t) }\end{array}$ \\
\hline \multicolumn{7}{|l|}{ Panel A. Males } \\
\hline Remains employed $(\mathrm{t}-1, \mathrm{t})$ & Ref & Ref & Ref & Ref & Ref & Ref \\
\hline $\begin{array}{l}\text { Employed }(\mathrm{t}-1) \& \\
\text { Completely retired (t) }\end{array}$ & $\begin{array}{c}0.012 \\
(0.019)\end{array}$ & $\begin{array}{c}0.020 \\
(0.023)\end{array}$ & $\begin{array}{l}-0.032 * \\
(0.019)\end{array}$ & $\begin{array}{c}0.029 \\
(0.018)\end{array}$ & $\begin{array}{c}-0.059 * * * \\
(0.021)\end{array}$ & $\begin{array}{c}0.030 * * \\
(0.014)\end{array}$ \\
\hline $\begin{array}{l}\text { Not completely retired (t- } \\
\text { 1) \& Completely retired } \\
\text { (t) }\end{array}$ & $\begin{array}{c}0.046 \\
(0.034)\end{array}$ & $\begin{array}{c}0.014 \\
(0.041)\end{array}$ & $\begin{array}{l}-0.060 * \\
(0.033)\end{array}$ & $\begin{array}{l}-0.055^{*} \\
(0.030)\end{array}$ & $\begin{array}{c}0.032 \\
(0.037)\end{array}$ & $\begin{array}{c}0.024 \\
(0.027)\end{array}$ \\
\hline $\begin{array}{l}\text { Remains completely } \\
\text { retired }(\mathrm{t}-1, \mathrm{t})\end{array}$ & $\begin{array}{c}0.040 * * \\
(0.016)\end{array}$ & $\begin{array}{l}-0.005 \\
(0.019)\end{array}$ & $\begin{array}{c}-0.035^{* *} \\
(0.017)\end{array}$ & $\begin{array}{l}-0.016 \\
(0.015)\end{array}$ & $\begin{array}{l}-0.018 \\
(0.018)\end{array}$ & $\begin{array}{c}0.034 * * * \\
(0.012)\end{array}$ \\
\hline \multicolumn{7}{|l|}{ Panel B. Females } \\
\hline Remains employed $(\mathrm{t}-1, \mathrm{t})$ & Ref & Ref & Ref & Ref & Ref & Ref \\
\hline $\begin{array}{l}\text { Employed }(\mathrm{t}-1) \& \\
\text { Completely retired }(\mathrm{t})\end{array}$ & $\begin{array}{l}-0.005 \\
(0.016)\end{array}$ & $\begin{array}{c}0.017 \\
(0.021)\end{array}$ & $\begin{array}{l}-0.012 \\
(0.019)\end{array}$ & $\begin{array}{l}0.042 * * \\
(0.018)\end{array}$ & $\begin{array}{c}-0.071 * * * \\
(0.022)\end{array}$ & $\begin{array}{l}0.029 * \\
(0.017)\end{array}$ \\
\hline $\begin{array}{l}\text { Not completely retired (t- } \\
\text { 1) \& Completely retired } \\
\text { (t) }\end{array}$ & $\begin{array}{c}0.026 \\
(0.026)\end{array}$ & $\begin{array}{c}0.004 \\
(0.033)\end{array}$ & $\begin{array}{l}-0.029 \\
(0.028)\end{array}$ & $\begin{array}{c}0.044 \\
(0.027)\end{array}$ & $\begin{array}{c}-0.065^{* *} \\
(0.032)\end{array}$ & $\begin{array}{c}0.021 \\
(0.024)\end{array}$ \\
\hline $\begin{array}{l}\text { Remains completely } \\
\text { retired }(\mathrm{t}-1, \mathrm{t})\end{array}$ & $\begin{array}{l}-0.003 \\
(0.013)\end{array}$ & $\begin{array}{c}0.023 \\
(0.017)\end{array}$ & $\begin{array}{l}-0.019 \\
(0.015)\end{array}$ & $\begin{array}{l}-0.006 \\
(0.014)\end{array}$ & $\begin{array}{l}-0.014 \\
(0.017)\end{array}$ & $\begin{array}{c}0.020 \\
(0.013)\end{array}$ \\
\hline
\end{tabular}

Notes. Each panel corresponds to a specific regression. Control variables are included: all other types of transitions on the labor market $(\mathrm{t}-1, \mathrm{t})$, age, age square, marital status, household size, the number of years of education, the logarithm of household income and year dummies. Robust standard errors in parentheses.

$* * * \mathrm{p}<0.01, * * \mathrm{p}<0.05, * \mathrm{p}<0.1$ 
Table 5. Effect of retirement on health shocks

\begin{tabular}{|c|c|c|c|}
\hline & $\begin{array}{c}(1) \\
\text { Unexpected } \\
\text { negative } \\
(\mathrm{t}-1, \mathrm{t})\end{array}$ & $\begin{array}{c}(2) \\
\text { Unexpected } \\
\text { same } \\
(\mathrm{t}-1, \mathrm{t}) \\
\end{array}$ & $\begin{array}{c}(3) \\
\text { Unexpected } \\
\text { positive } \\
(\mathrm{t}-1, \mathrm{t})\end{array}$ \\
\hline \multicolumn{4}{|l|}{ Panel A. Males } \\
\hline Employed (t) & Ref & Ref & Ref \\
\hline \multirow[t]{2}{*}{ Completely retired $(\mathrm{t})$} & -0.003 & -0.021 & $0.041 * * *$ \\
\hline & $(0.009)$ & $(0.014)$ & $(0.013)$ \\
\hline Observations & 22,836 & 22,836 & 22,836 \\
\hline Number of persons & 3,905 & 3,905 & 3,905 \\
\hline \multicolumn{4}{|l|}{ Panel B. Females } \\
\hline Employed (t) & Ref & Ref & Ref \\
\hline \multirow[t]{2}{*}{ Completely retired $(\mathrm{t})$} & 0.003 & 0.016 & -0.017 \\
\hline & $(0.009)$ & $(0.013)$ & $(0.011)$ \\
\hline Observations & 25,165 & 25,165 & 25,165 \\
\hline Number of persons & 4,269 & 4,269 & 4,269 \\
\hline \multicolumn{4}{|l|}{ Panel C. Males } \\
\hline Remains employed $(\mathrm{t}-1, \mathrm{t})$ & Ref & Ref & Ref \\
\hline \multirow[t]{2}{*}{ Employed (t-1) \& Completely retired (t) } & 0.025 & -0.027 & $0.046 * *$ \\
\hline & $(0.015)$ & $(0.021)$ & $(0.021)$ \\
\hline \multirow[t]{2}{*}{ Not completely retired (t-1) \& Completely retired (t) } & -0.035 & -0.013 & $0.104 * * *$ \\
\hline & $(0.026)$ & $(0.038)$ & $(0.037)$ \\
\hline \multirow[t]{2}{*}{ Remains completely retired $(\mathrm{t}-1, \mathrm{t})$} & $-0.024 * *$ & -0.010 & $0.052 * * *$ \\
\hline & $(0.011)$ & $(0.018)$ & $(0.017)$ \\
\hline \multicolumn{4}{|l|}{ Panel D. Females } \\
\hline Remains employed $(\mathrm{t}-1, \mathrm{t})$ & Ref & Ref & Ref \\
\hline \multirow[t]{2}{*}{ Employed (t-1) \& Completely retired (t) } & 0.021 & -0.001 & -0.022 \\
\hline & $(0.016)$ & $(0.021)$ & $(0.017)$ \\
\hline \multirow[t]{2}{*}{ Not completely retired (t-1) \& Completely retired (t) } & 0.022 & -0.002 & -0.018 \\
\hline & $(0.025)$ & $(0.029)$ & $(0.028)$ \\
\hline \multirow[t]{2}{*}{ Remains completely retired $(\mathrm{t}-1, \mathrm{t})$} & -0.016 & $0.027 *$ & -0.009 \\
\hline & $(0.011)$ & $(0.016)$ & $(0.014)$ \\
\hline
\end{tabular}

Notes. Each panel corresponds to a specific regression. In Panels A and B, controls for not completely retired (t) and for never in the workforce ( $\mathrm{t}$ ) are included. In Panels $\mathrm{C}$ and D, controls for all other transitions in the labor market $(\mathrm{t}-1, \mathrm{t})$ are included. In all panels, the following control variables are included: age, age square, marital status, household size, the number of years of education, the logarithm of household income and year dummies. Robust standard errors in parentheses. $* * * \mathrm{p}<0.01, * * \mathrm{p}<0.05, * \mathrm{p}<0.1$. 
Table 6. Effect of retirement on health shocks using the evolution of SF-36 scores, for males

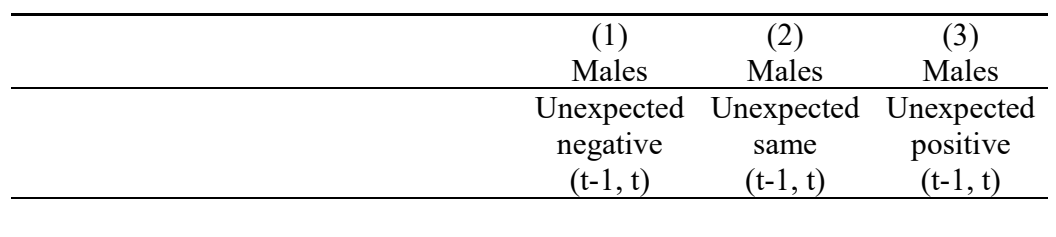

\section{PHYSICAL HEALTH}

Panel A. Physical functioning

$\begin{array}{lll}-0.018 & -0.002 & 0.034 * *\end{array}$

$\begin{array}{lll}(0.012) & (0.010) & (0.014)\end{array}$

Panel B. Role functioning/physical Completely retired (t) $\begin{array}{lll}-0.008 & -0.010 & 0.047 * * *\end{array}$

$\begin{array}{lll}(0.011) & (0.014) & (0.014)\end{array}$

Panel C. Bodily pain

Completely retired $(\mathrm{t})$

$\begin{array}{lll}-0.013 & 0.005 & 0.029 * *\end{array}$

$\begin{array}{lll}(0.013) & (0.010) & (0.013)\end{array}$

\begin{tabular}{lccc} 
Panel D. General health & & & \\
Completely retired (t) & -0.007 & -0.012 & $0.047 * * *$ \\
& $(0.014)$ & $(0.008)$ & $(0.014)$ \\
\hline
\end{tabular}

\section{MENTAL HEALTH}

Panel E. Vitality

Completely retired $(t)$

$\begin{array}{lll}-0.028 * * & -0.009 & 0.041 * * *\end{array}$

$\begin{array}{lll}(0.014) \quad(0.008) & (0.014)\end{array}$

Panel F. Social functioning

Completely retired $(\mathrm{t})$

$\begin{array}{lll}-0.011 & -0.004 & 0.028 * *\end{array}$

$\begin{array}{lll}(0.011) & (0.012) & (0.013)\end{array}$

Panel G. Mental health

Completely retired (t)

$\begin{array}{lll}-0.005 & -0.000 & 0.011\end{array}$

$\begin{array}{lll}(0.012) & (0.007) & (0.012)\end{array}$

Panel H. Role functioning/emotional

Completely retired $(t)$

$0.002 \quad-0.013 \quad 0.049 * * *$

$\begin{array}{lll}(0.008) & (0.014) \quad(0.014)\end{array}$

$\begin{array}{lccc}\text { Observations } & 23,799 & 23,799 & 23,799 \\ \text { Number of persons } & 4,047 & 4,047 & 4,047\end{array}$

Notes. Each panel corresponds to a specific regression. Control variables are included: not completely retired $(\mathrm{t})$, never in the workforce $(\mathrm{t})$, age, age square, marital status, household size, the number of years of education, the logarithm of household income and year dummies. Robust standard errors in parentheses.

$* * * \mathrm{p}<0.01, * * \mathrm{p}<0.05, * \mathrm{p}<0.1$. 
Table 7. Effect of retirement on health shocks using the evolution of SF-36 scores, for females

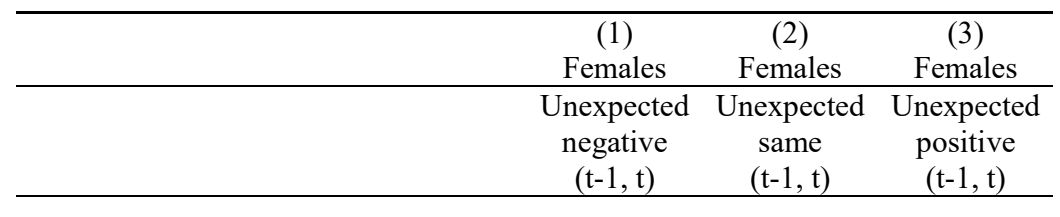

\section{PHYSICAL HEALTH}

Panel A. Physical functioning

$\begin{array}{lll}-0.004 & -0.001 & 0.019 * \\ \end{array}$

$\begin{array}{lll}(0.013) & (0.008) & (0.011)\end{array}$

Panel B. Role functioning/physical

Completely retired $(t)$

$\begin{array}{lll}0.020 * * & 0.001 & -0.008\end{array}$

$\begin{array}{lll}(0.010) & (0.012) & (0.012)\end{array}$

Panel C. Bodily pain

Completely retired (t)

$\begin{array}{lll}-0.005 & -0.004 & 0.013\end{array}$

$\begin{array}{lll}(0.012) & (0.010) & (0.012)\end{array}$

\section{Panel D. General health}

Completely retired $(\mathrm{t})$

$\begin{array}{ll}-0.011 & 0.007\end{array}$

$(0.013)$

(0.008)

$(0.013)$

\section{MENTAL HEALTH}

Panel E. Vitality

Completely retired $(t)$

$\begin{array}{lll}-0.026 * * & 0.013 * & 0.016\end{array}$

$\begin{array}{lll}(0.013) & (0.007) & (0.012)\end{array}$

Panel F. Social functioning

Completely retired $(\mathrm{t})$

$\begin{array}{lll}-0.007 & 0.007 & 0.005\end{array}$

$\begin{array}{lll}(0.011) & (0.011) & (0.012)\end{array}$

\section{Panel G. Mental health}

Completely retired (t)

$\begin{array}{lll}-0.005 & -0.000 & 0.011\end{array}$

$\begin{array}{lll}(0.012) & (0.007) \quad(0.012)\end{array}$

Panel H. Role functioning/emotional

Completely retired (t)

0.014* $\quad-0.003 \quad 0.000$

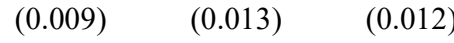

$\begin{array}{lccc}\text { Observations } & 26,195 & 26,195 & 26,195 \\ \text { Number of persons } & 4,398 & 4,398 & 4,398\end{array}$

Notes. Each panel corresponds to a specific regression. Control variables are included: not completely retired (t), never in the workforce $(\mathrm{t})$, age, age square, marital status, household size, the number of years of education, the logarithm of household income and year dummies. Robust standard errors in parentheses.

$* * * \mathrm{p}<0.01, * * \mathrm{p}<0.05, * \mathrm{p}<0.1$. 


\section{FIGURES}

Figure 1. Health shocks around the time of complete retirement

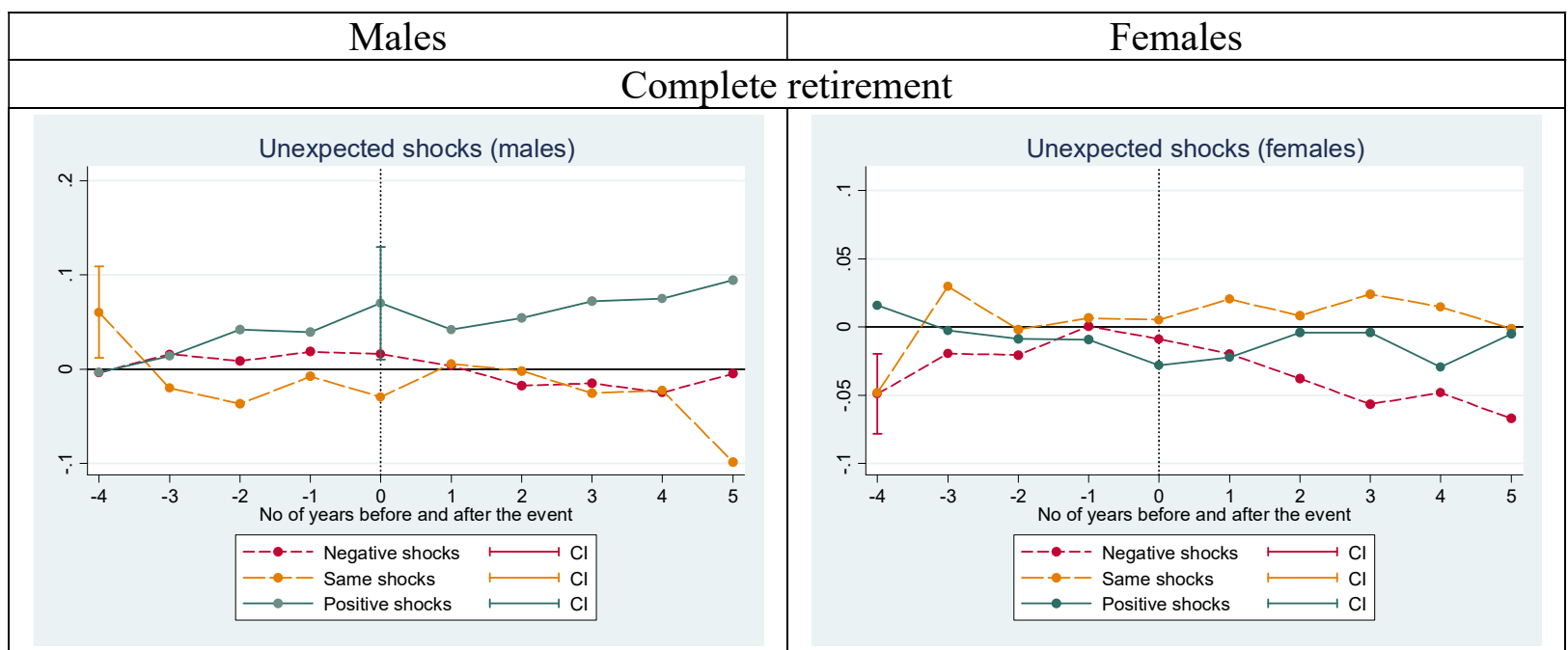

Notes. The sample contains individuals aged 50-75 who transition to complete retirement. Individuals 5 years or more before complete retirement are the reference category. Confidence intervals (at the $10 \%$ level) are represented only when the coefficient is statistically significant. 
Figure 2. Shocks around the time of an unemployment spell

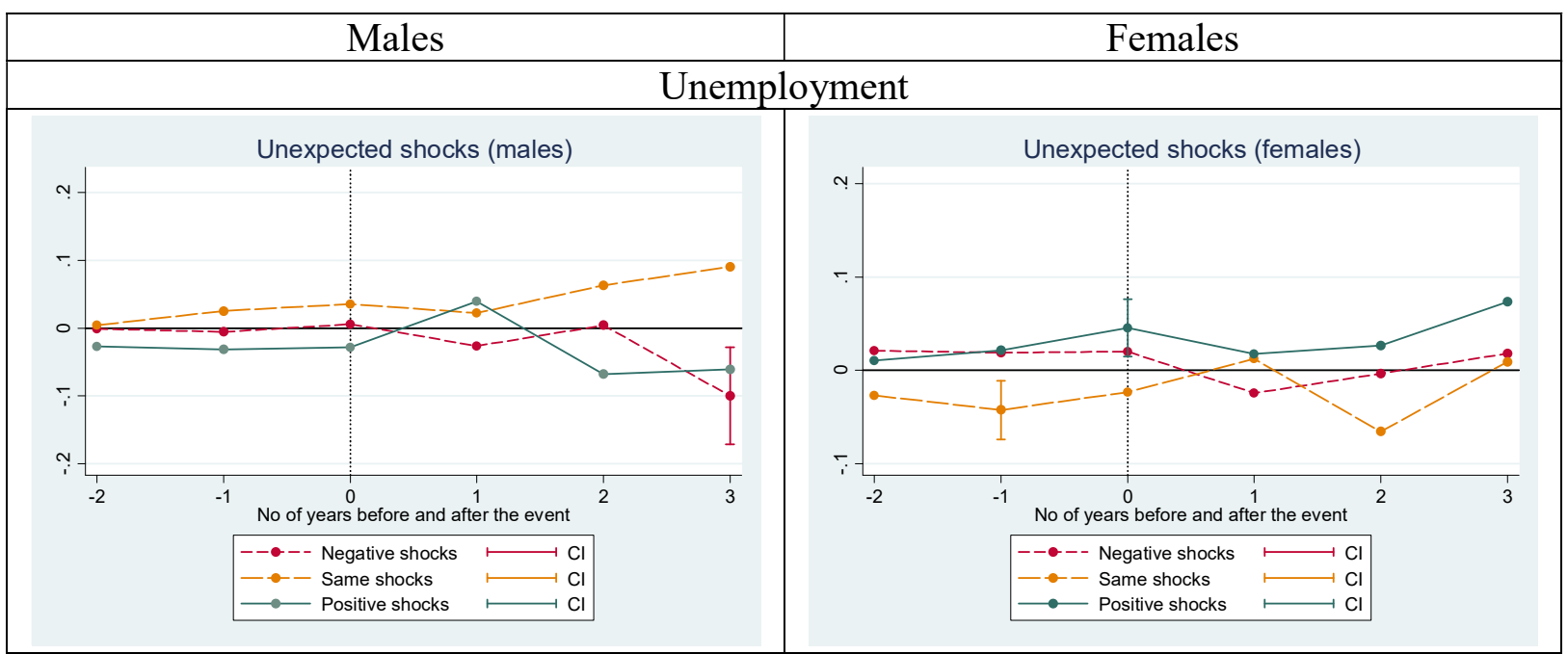

Notes. The sample contains individuals less than 55 years of age. Individuals 3 years or more before unemployment are the reference categories. Confidence intervals (at the $10 \%$ level) are represented only when the coefficient is statistically significant. 
APPENDIX (online-only supplementary material)

Table A1. Detailed effect of retirement on health shocks

\begin{tabular}{|c|c|c|c|c|c|c|c|c|c|}
\hline & $\begin{array}{c}(1) \\
\text { Doesn't } \\
\text { know } \\
\text { whether } \\
\text { health will } \\
\text { get worse } \\
\text { (t-1) } \\
\text { \& Health is } \\
\text { worse } \\
\text { (t) }\end{array}$ & $\begin{array}{c}(2) \\
\text { Expects } \\
\text { same or } \\
\text { better health } \\
\text { (t-1) } \\
\& \text { Health is } \\
\text { worse } \\
\text { (t) }\end{array}$ & $\begin{array}{c}(3) \\
\text { Doesn't } \\
\text { know } \\
\text { whether } \\
\text { health will } \\
\text { get worse } \\
\text { (t-1) } \\
\text { \& Health is } \\
\text { the same } \\
(\mathrm{t})\end{array}$ & $\begin{array}{c}(4) \\
\text { Expects } \\
\text { worse } \\
\text { health } \\
(\mathrm{t}-1) \\
\text { \& Health is } \\
\text { the same } \\
\text { (t) }\end{array}$ & $\begin{array}{c}(5) \\
\text { Expects } \\
\text { worse } \\
\text { health } \\
(\mathrm{t}-1) \\
\text { \& Health is } \\
\text { better } \\
(\mathrm{t})\end{array}$ & $\begin{array}{c}(6) \\
\text { Doesn't } \\
\text { know } \\
\text { whether } \\
\text { health will } \\
\text { get worse } \\
\text { (t-1) } \\
\text { \& Health is } \\
\text { better } \\
\text { (t) }\end{array}$ & $\begin{array}{c}(7) \\
\text { Expects } \\
\text { worse } \\
\text { health } \\
(\mathrm{t}-1) \\
\& \text { Health } \\
\text { is worse } \\
\text { (t) }\end{array}$ & $\begin{array}{c}(8) \\
\text { Expects } \\
\text { same or } \\
\text { better } \\
\text { health } \\
(\mathrm{t}-1) \\
\& \\
\text { Health is } \\
\text { the same } \\
(\mathrm{t})\end{array}$ & $\begin{array}{c}(9) \\
\text { Expects } \\
\text { same or } \\
\text { better } \\
\text { health } \\
(\mathrm{t}-1) \\
\& \\
\text { Health is } \\
\text { better } \\
(\mathrm{t})\end{array}$ \\
\hline & $\begin{array}{l}\text { Unexpected } \\
\text { negative } \\
(\mathrm{t}-1, \mathrm{t})\end{array}$ & $\begin{array}{c}\text { Unexpected } \\
\text { negative } \\
(\mathrm{t}-1, \mathrm{t})\end{array}$ & $\begin{array}{c}\text { Unexpected } \\
\text { same } \\
(\mathrm{t}-1, \mathrm{t})\end{array}$ & $\begin{array}{c}\text { Unexpected } \\
\text { positive } \\
(\mathrm{t}-1, \mathrm{t}) \\
\end{array}$ & $\begin{array}{l}\text { Unexpected } \\
\text { positive } \\
(\mathrm{t}-1, \mathrm{t}) \\
\end{array}$ & $\begin{array}{l}\text { Unexpected } \\
\text { positive } \\
(\mathrm{t}-1, \mathrm{t}) \\
\end{array}$ & $\begin{array}{c}\text { Expected } \\
\text { worse } \\
(\mathrm{t}-1, \mathrm{t}) \\
\end{array}$ & & \\
\hline \multicolumn{10}{|c|}{ Panel A. Males } \\
\hline Employed (t) & Ref & Ref & Ref & Ref & Ref & Ref & Ref & Ref & Ref \\
\hline $\begin{array}{l}\text { Completely } \\
\text { retired }(t)\end{array}$ & $\begin{array}{l}-0.000 \\
(0.008)\end{array}$ & $\begin{array}{l}-0.003 \\
(0.005)\end{array}$ & $\begin{array}{l}-0.021 \\
(0.014)\end{array}$ & $\begin{array}{l}0.021^{*} \\
(0.012)\end{array}$ & $\begin{array}{c}0.002 \\
(0.004)\end{array}$ & $\begin{array}{c}0.018 * * * \\
(0.007)\end{array}$ & $\begin{array}{c}0.014 \\
(0.010)\end{array}$ & $\begin{array}{c}-0.032 * * \\
(0.013)\end{array}$ & $\begin{array}{c}0.001 \\
(0.006)\end{array}$ \\
\hline Observations & 22,836 & 22,836 & 22,836 & 22,836 & 22,836 & 22,836 & 22,836 & 22,836 & 22,836 \\
\hline $\begin{array}{l}\text { Number of } \\
\text { persons }\end{array}$ & 3,905 & 3,905 & 3,905 & 3,905 & 3,905 & 3,905 & 3,905 & 3,905 & 3,905 \\
\hline \multicolumn{10}{|c|}{ Panel B. Females } \\
\hline Employed & Ref & Ref & Ref & Ref & Ref & Ref & Ref & Ref & Ref \\
\hline $\begin{array}{l}\text { Completely } \\
\text { retired }(t)\end{array}$ & $\begin{array}{c}0.000 \\
(0.008)\end{array}$ & $\begin{array}{c}0.003 \\
(0.006)\end{array}$ & $\begin{array}{c}0.016 \\
(0.013)\end{array}$ & $\begin{array}{l}-0.015^{*} \\
(0.009)\end{array}$ & $\begin{array}{c}0.001 \\
(0.005)\end{array}$ & $\begin{array}{l}-0.003 \\
(0.007)\end{array}$ & $\begin{array}{l}0.014 * \\
(0.008)\end{array}$ & $\begin{array}{c}-0.032^{* *} \\
(0.013)\end{array}$ & $\begin{array}{l}0.016^{*} \\
(0.008)\end{array}$ \\
\hline Observations & 25,165 & 25,165 & 25,165 & 25,165 & 25,165 & 25,165 & 25,165 & 25,165 & 25,165 \\
\hline $\begin{array}{l}\text { Number of } \\
\text { persons }\end{array}$ & 4,269 & 4,269 & 4,269 & 4,269 & 4,269 & 4,269 & 4,269 & 4,269 & 4,269 \\
\hline
\end{tabular}

Notes. Each panel corresponds to a specific regression. Control variables are included: not completely retired (t), never in the workforce ( $\mathrm{t}$ ), age, age square, marital status, household size, the number of years of education, the logarithm of household income and year dummies. Robust standard errors in parentheses.

$* * * \mathrm{p}<0.01, * * \mathrm{p}<0.05, * \mathrm{p}<0.1$ 
Table A2. Results for the restricted sample

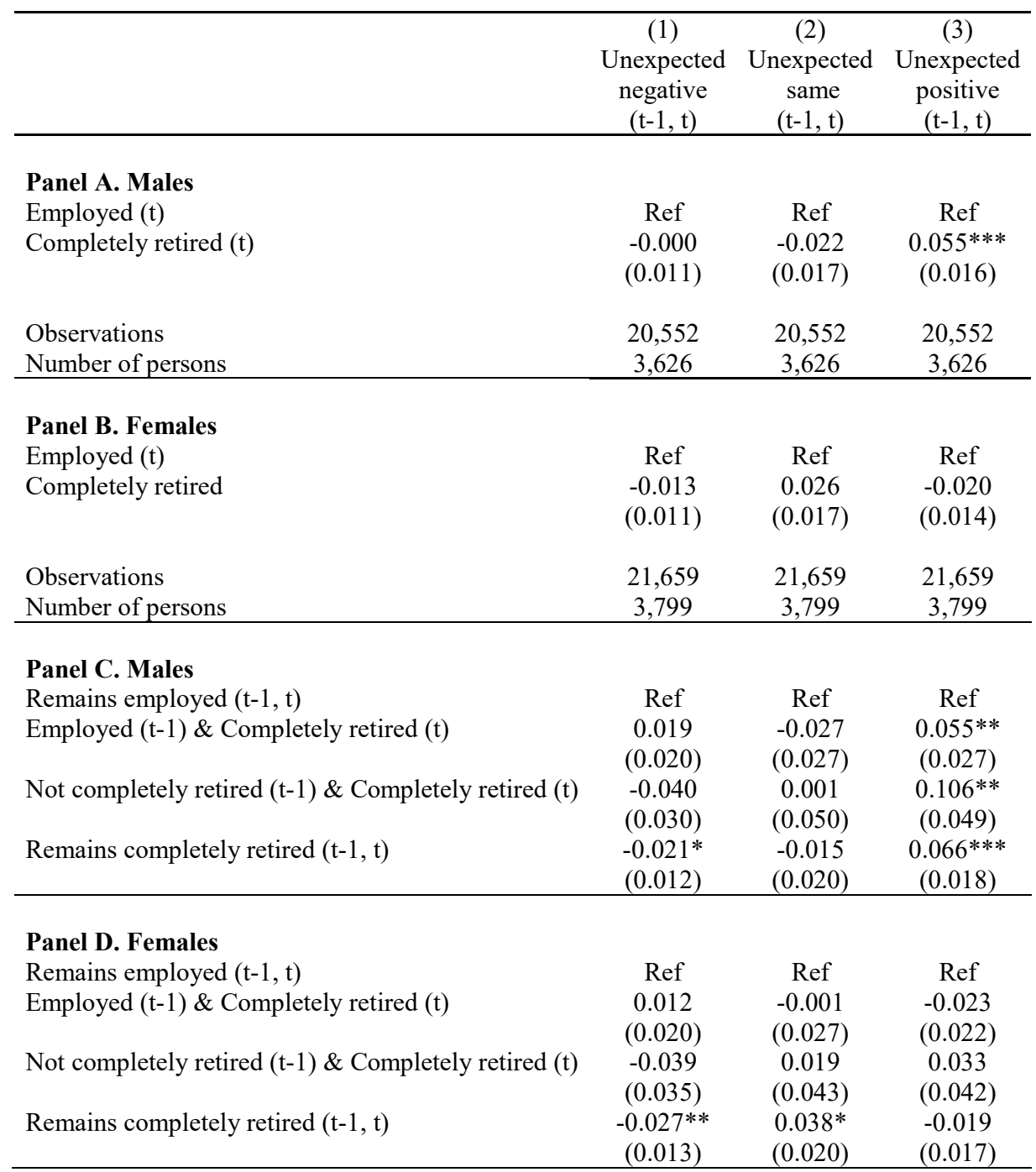

Notes. In the restricted sample, we drop individuals who retire several times. Each panel corresponds to a specific regression. In Panels A and B, controls for not completely retired $(t)$ and never in the workforce $(t)$ are included. In Panels $\mathrm{C}$ and $\mathrm{D}$, controls for all other transitions in the labor market $(\mathrm{t}-1, \mathrm{t})$ are included. In all panels, the following control variables are included: age, age square, marital status, household size, the number of years of education, the logarithm of household income and year dummies. Robust standard errors in parentheses.

$* * * \mathrm{p}<0.01, * * \mathrm{p}<0.05, * \mathrm{p}<0.1$ 
Table A3. Main model including lagged health status

\begin{tabular}{|c|c|c|c|}
\hline & $\begin{array}{c}(1) \\
\text { Unexpected } \\
\text { negative } \\
(\mathrm{t}-1, \mathrm{t})\end{array}$ & $\begin{array}{c}(2) \\
\text { Unexpected } \\
\text { same } \\
(\mathrm{t}-1, \mathrm{t}) \\
\end{array}$ & $\begin{array}{c}(3) \\
\text { Unexpected } \\
\text { positive } \\
(\mathrm{t}-1, \mathrm{t}) \\
\end{array}$ \\
\hline \multicolumn{4}{|l|}{ Panel A. Males } \\
\hline Employed (t) & Ref & Ref & Ref \\
\hline Completely retired $(\mathrm{t})$ & $\begin{array}{l}-0.000 \\
(0.009)\end{array}$ & $\begin{array}{l}-0.021 \\
(0.014)\end{array}$ & $\begin{array}{c}0.035^{* * *} * \\
(0.013)\end{array}$ \\
\hline Self-assessed health: Poor (t-1) & $\begin{array}{c}-0.097 * * * \\
(0.020)\end{array}$ & $\begin{array}{l}-0.035 \\
(0.022)\end{array}$ & $\begin{array}{c}0.202 * * * \\
(0.026)\end{array}$ \\
\hline Self-assessed health: Fair (t-1) & $\begin{array}{c}-0.051 * * * \\
(0.011)\end{array}$ & $\begin{array}{l}-0.023 \\
(0.014)\end{array}$ & $\begin{array}{c}0.166 * * * \\
(0.014)\end{array}$ \\
\hline Self-assessed health: Good (t-1) & $\begin{array}{c}-0.013 * * \\
(0.006)\end{array}$ & $\begin{array}{l}0.016^{*} \\
(0.010)\end{array}$ & $\begin{array}{c}0.077 * * * \\
(0.008)\end{array}$ \\
\hline Self-assessed health: Very good (t-1) & Ref & Ref & Ref \\
\hline Self-assessed health: Excellent (t-1) & $\begin{array}{c}0.000 \\
(0.007)\end{array}$ & $\begin{array}{c}-0.030^{* *} \\
(0.014)\end{array}$ & $\begin{array}{c}-0.055^{* * *} \\
(0.011)\end{array}$ \\
\hline Observations & 22,573 & 22,573 & 22,573 \\
\hline Number of persons & 3,892 & 3,892 & 3,892 \\
\hline \multicolumn{4}{|l|}{ Panel B. Females } \\
\hline Employed (t) & Ref & Ref & Ref \\
\hline Completely retired $(\mathrm{t})$ & $\begin{array}{c}0.007 \\
(0.009)\end{array}$ & $\begin{array}{c}0.015 \\
(0.013)\end{array}$ & $\begin{array}{c}-0.024 * * \\
(0.011)\end{array}$ \\
\hline Self-assessed health: Poor (t-1) & $\begin{array}{c}-0.103 * * * \\
(0.019)\end{array}$ & $\begin{array}{c}-0.040^{* *} \\
(0.019)\end{array}$ & $\begin{array}{c}0.204 * * * \\
(0.023)\end{array}$ \\
\hline Self-assessed health: Fair (t-1) & $\begin{array}{c}-0.050^{* * *} \\
(0.011)\end{array}$ & $\begin{array}{c}-0.028^{* *} \\
(0.013)\end{array}$ & $\begin{array}{c}0.206^{* * *} \\
(0.013)\end{array}$ \\
\hline Self-assessed health: Good (t-1) & $\begin{array}{c}-0.019 * * * \\
(0.006)\end{array}$ & $\begin{array}{c}0.024 * * * \\
(0.009)\end{array}$ & $\begin{array}{c}0.083 * * * \\
(0.008)\end{array}$ \\
\hline Self-assessed health: Very good (t-1) & Ref & Ref & Ref \\
\hline Self-assessed health: Excellent (t-1) & $\begin{array}{c}0.006 \\
(0.009)\end{array}$ & $\begin{array}{c}-0.048^{* * *} \\
(0.012)\end{array}$ & $\begin{array}{c}-0.039 * * * \\
(0.009)\end{array}$ \\
\hline Observations & 24,802 & 24,802 & 24,802 \\
\hline Number of persons & 4,251 & 4,251 & 4,251 \\
\hline
\end{tabular}

Notes. Each panel corresponds to a specific regression. Control variables are included: not completely retired (t), never in the workforce ( $\mathrm{t}$ ), age, age square, marital status, household size, the number of years of education, the logarithm of household income and year dummies. Robust standard errors in parentheses.

$* * * \mathrm{p}<0.01, * * \mathrm{p}<0.05, * \mathrm{p}<0.1$. 
Table A4. Main model using longitudinal weights

\begin{tabular}{lccc}
\hline & $\begin{array}{c}(1) \\
\text { Unexpected } \\
\text { negative } \\
(\mathrm{t}-1, \mathrm{t})\end{array}$ & $\begin{array}{c}(2) \\
\text { Unexpected } \\
\text { same } \\
(\mathrm{t}-1, \mathrm{t})\end{array}$ & $\begin{array}{c}(3) \\
\text { Unexpected } \\
\text { positive } \\
(\mathrm{t}-1, \mathrm{t})\end{array}$ \\
\hline Males & Ref & Ref & Ref \\
Employed ( $\mathrm{t})$ & 0.000 & $-0.031^{*}$ & $\begin{array}{c}0.036^{* *} \\
\text { Completely retired (t) }\end{array}$ \\
& $(0.012)$ & $(0.017)$ & $(0.016)$ \\
Observations & 16,424 & 16,424 & 16,424 \\
Number of persons & 2,040 & 2,040 & 2,040 \\
\hline & & & \\
Females & & & \\
Employed ( $\mathrm{t})$ & $\mathrm{Ref}$ & $\mathrm{Ref}$ & $\mathrm{Ref}$ \\
Completely retired (t) & 0.002 & 0.023 & $-0.026^{*}$ \\
& $(0.010)$ & $(0.016)$ & $(0.013)$ \\
Observations & & & \\
Number of persons & 2,353 & 2,353 & 2,353 \\
\hline
\end{tabular}

Notes. Control variables are included: not completely retired (t), never in the workforce (t), age, age square, marital status, household size, the number of years of education, the logarithm of household income and year dummies. Longitudinal weights are also included. Robust standard errors in parentheses.

$* * * \mathrm{p}<0.01, * * \mathrm{p}<0.05, * \mathrm{p}<0.1$. 
Table A5. Effect of health shocks on life satisfaction

\begin{tabular}{|c|c|c|c|c|}
\hline & $\begin{array}{c}(1) \\
\text { Males } \\
\text { Life } \\
\text { satisfaction } \\
(\mathrm{t}) \\
\end{array}$ & $\begin{array}{c}(2) \\
\text { Males } \\
\text { Life } \\
\text { satisfaction } \\
(\mathrm{t}) \\
\end{array}$ & $\begin{array}{c}(3) \\
\text { Females } \\
\text { Life } \\
\text { satisfaction } \\
\text { (t) } \\
\end{array}$ & $\begin{array}{c}(4) \\
\text { Females } \\
\text { Life } \\
\text { satisfaction } \\
(\mathrm{t}) \\
\end{array}$ \\
\hline $\begin{array}{l}\text { Expectations (t-1) } \\
\text { Expects worse health } \\
\text { Doesn't know whether health will } \\
\text { get worse } \\
\text { Expects same or better health }\end{array}$ & $\begin{array}{l}\text { Ref } \\
0.057 * * \\
(0.023) \\
0.068 * * * \\
(0.026)\end{array}$ & & $\begin{array}{c}\text { Ref } \\
0.000 \\
(0.028) \\
0.020 \\
(0.031)\end{array}$ & \\
\hline $\begin{array}{l}\text { Overall health transitions (t) } \\
\text { Health is worse } \\
\text { Health is the same } \\
\text { Health is better }\end{array}$ & $\begin{array}{l}\text { Ref } \\
0.274 * * * \\
(0.026) \\
0.357 * * * \\
(0.034)\end{array}$ & & $\begin{array}{l}\text { Ref } \\
0.341^{* * *} \\
(0.026) \\
0.469 * * * \\
(0.033)\end{array}$ & \\
\hline $\begin{array}{l}\text { Unexpected and expected } \\
\text { changes }(t-1, t) \\
\text { Unexpected negative }\end{array}$ & & Ref & & Ref \\
\hline Unexpected same & & $\begin{array}{c}0.264 * * * \\
(0.031)\end{array}$ & & $\begin{array}{c}0.338^{* * *} \\
(0.032)\end{array}$ \\
\hline Unexpected positive & & $\begin{array}{c}0.242 * * * \\
(0.032)\end{array}$ & & $\begin{array}{c}0.399 * * * \\
(0.037)\end{array}$ \\
\hline $\begin{array}{l}\text { Expected worse: Expects worse } \\
\text { health }(\mathrm{t}-1) \text { \& Health is worse }(\mathrm{t})\end{array}$ & & $\begin{array}{l}-0.071 \\
(0.046)\end{array}$ & & $\begin{array}{c}0.019 \\
(0.049)\end{array}$ \\
\hline $\begin{array}{l}\text { Expects same or better health }(t-1) \\
\& \text { Health is the same }(t)\end{array}$ & & $\begin{array}{c}0.261^{* * *} \\
(0.032)\end{array}$ & & $\begin{array}{c}0.347 * * * \\
(0.033)\end{array}$ \\
\hline $\begin{array}{l}\text { Expects same or better health }(\mathrm{t}-1) \\
\& \text { Health is better }(\mathrm{t})\end{array}$ & & $\begin{array}{c}0.333 * * * \\
(0.042)\end{array}$ & & $\begin{array}{c}0.475^{* * *} \\
(0.041)\end{array}$ \\
\hline $\begin{array}{l}\text { Labor market status (t) } \\
\text { Employed } \\
\text { Completely retired }\end{array}$ & $\begin{array}{c}\text { Ref } \\
0.052 \\
(0.038)\end{array}$ & $\begin{array}{l}\text { Ref } \\
0.053 \\
(0.038)\end{array}$ & $\begin{array}{c}\text { Ref } \\
0.064 \\
(0.039)\end{array}$ & $\begin{array}{l}\text { Ref } \\
0.064 * \\
(0.039)\end{array}$ \\
\hline $\begin{array}{l}\text { Observations } \\
\text { Number of persons }\end{array}$ & $\begin{array}{c}22,831 \\
3,905\end{array}$ & $\begin{array}{c}22,831 \\
3,905\end{array}$ & $\begin{array}{c}25,150 \\
4,269\end{array}$ & $\begin{array}{c}25,150 \\
4,269\end{array}$ \\
\hline
\end{tabular}

Notes. Control variables are included: not completely retired $(\mathrm{t})$, never in the workforce (t), age, age square, marital status, household size, the number of years of education, the logarithm of household income and year dummies. Robust standard errors in parentheses.

$* * * \mathrm{p}<0.01, * * \mathrm{p}<0.05, * \mathrm{p}<0.1$. 
Figure A1. Shocks around the time of marriage, separation/divorce and widowhood

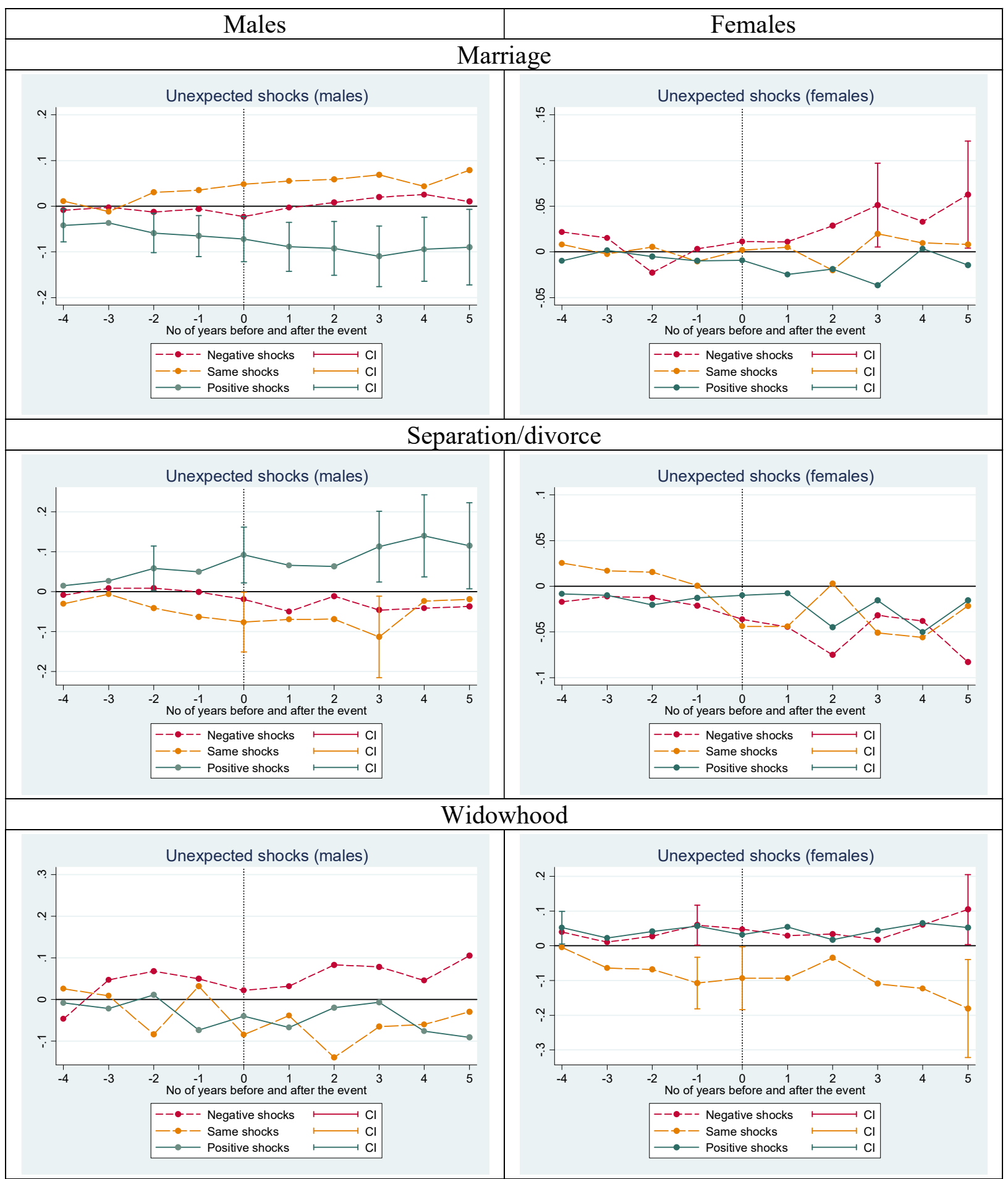

Notes. The samples contain individuals of all ages. Individuals 5 years or more before marriage, separation/divorce and widowhood are the reference categories. Confidence intervals (at the $10 \%$ level) are represented only when the coefficient is statistically significant. 